\title{
New reports of Paratethyan ostracods affinity from the Mediterranean Basin (Sicily, Italy)
}

\author{
Francesco Sciuto, Angela Baldanza, Rim Temani, and Giovanni Privitera
}

\begin{abstract}
During the late Messinian post evaporitic phase, in the eastern region between the Alps and the Aral Sea, the Paratethys was reduced to a number of large independent basins (Pannonian Basin, Pontic Basin and Caspian-Aral Basin) separated by vast continental regions. At the same time, in the Paleomediterranean region, discontinuous shallow-water basins were formed on the existing substrate. In these basins predominantly siliciclastic sediments were deposited consisting of gravels, sands, marls and silts, and containing continental oligohaline faunas. These sedimentary facies, which are largely exposed in Italy and in other Mediterranean regions, are called "Lago-Mare". These sediments overlapping the Messinian evaporitic layers in apparent conformity have already been reported from western Sicily. Now they have been sampled and analyzed in five different localities in eastern Sicily. These sedimentary facies are called "Congeria" strata (marl containing oligohaline faunas) and "Arenazzolo" (reddish arkosic sands containing brackish or freshwater ostracods). From these levels, which correspond to two different sedimentation environments, an oligotypic ostracod fauna was extracted consisting of species belonging to the genera Tyrrhenocythere, Loxoconcha and Cyprideis. Among them, Loxoconcha muelleri (Mehes, 1908) and Cyprideis anlavauxensis Carbonnel, 1979, are reported for the first time from Sicily. Two other species are new to science; one is described as Tyrrhenocythere pulcherrima sp. nov. herein, whereas, the other one is left in open nomenclature as Loxoconcha n. sp.
\end{abstract}

Francesco Sciuto. Department of Biological, Geological and Environmental Science, University of Catania, Corso Italia 55, 95129 Catania, Italy. fsciuto@unict.it

Angela Baldanza. Department of Physics and Geology, University of Perugia, Via Pascoli, 06123 Perugia, Italy. angela.baldanza@unipg.it

Rim Temani. Office National des Mines, 24, rue de l'énergie, 2035 La Charguia, Tunis, Tunisia.

rim.temani@yahoo.fr

Giovanni Privitera. Technical Study of Energy and Environment, Via Municipio, Misterbianco, Catania.

giovpriv@tim.it

http://zoobank.org/DA7F28E3-631B-4F93-B5B9-91A4B6CAB46E

Sciuto, Francesco, Baldanza, Angela, Temani, Rim, and Privitera, Giovanni. 2018. New reports of Paratethyan ostracods affinity from the Mediterranean Basin (Sicily, Italy). Palaeontologia Electronica 21.1.12A 1-19. https://doi.org/10.26879/800

palaeo-electronica.org/content/2018/2174-paratethyan-ostracods

Copyright: April 2018 Palaeontological Association.

This is an open access article distributed under the terms of Attribution-NonCommercial-ShareAlike 4.0 International (CC BY-NC-SA

4.0), which permits users to copy and redistribute the material in any medium or format, provided it is not used for commercial

purposes and the original author and source are credited, with indications if any changes are made.

creativecommons.org/licenses/by-nc-sa/4.0/ 
Keywords: late Messinian; ostracods; Paratethys; paleoenvironmental evolution; new species

\section{INTRODUCTION}

The temporary restricted connection to complete closure of the communication with the Atlantic Ocean during the Messinian Stage determined the formation of euxinic environments in the Paleomediterranean Basin and gave rise to what is called Messinian Salinity Crisis (Hsü et al., 1973). During this short period, which lasted about $640 \mathrm{kyr}$ (Krijgsman et al., 1999; Roveri et al., 2014), various and sometimes considerable thicknesses (from few to thousands of meters) of evaporites were deposited in virtually the entire Mediterranean Basin area (Rouchy and Caruso, 2006). In Sicily, the Messinian evaporitic succession is present in the Caltanissetta Basin where it is classically divided into two cycles: a lower cycle, comprising the primary evaporitic facies (the Lower Gypsum unit) and an upper cycle, lying unconformably on the lower one, comprising cyclic alternations of primary gypsum and calcareous sediments (Roveri et al., 2008). In eastern Sicily the Messinian evaporites, represented mainly by "The Calcare di Base" and gypsum, were deposited in pre-existing basins created by a synsedimentary tectonics (Pedley and Grasso, 1992; Caruso et al., 2015). This gypsum appears to be related to the "Primary Lower Gypsum" of the Central Sicily Basin (Di Geronimo et al., 1989; Pedley and Grasso, 1992; Roveri et al., 2006, 2008).

During the Late Messinian post evaporitic phase, several parts of the Mediterranean Basin were affected by intense continentalization with strong subaerial erosion phenomena and chemical dissolution of Messinian gypsum and Calcare di Base, and, in the widespread lower basin area, deposition of sedimentary facies characterized by brackish to fresh water fauna (Orszag-Sperber et al., 2000; Rouchy et al., 2007; Gliozzi et al., 2007). This sedimentary facies, called "Lago-Mare" sensu Ruggieri (1967), crops out discontinuously but widely in all the Mediterranean Basin from the Eastern to the Western Basin (Orszag-Sperber et al., 2000; Rouchy and Caruso, 2006).

In Sicily, but also in other geographical areas of the Mediterranean Basin, these sediments seem to have at least two different facies: the first one consists of marl containing oligohaline faunas ("Congeria") (Di Geronimo et al., 1989), the second one consists of reddish arkosic sands ("Arenazzolo") containing brackish to fresh water ostracods (Bonaduce and Sgarella, 1999; Roveri et al., 2008; present paper). Sometimes these facies represent mesohaline to hyperhaline shallow water environments with low oxygen content (Grossi et al., 2015). The origin of this fauna was probably related to overflowing of the Pannonian-Pontian Parathetyan waters (Gliozzi et al., 2007; Stoica et al., 2016) or to the colonisation of shallow lakes formed at various altitudes, on the top of the Messinian strata and fueled by rainwater (Orszag-Sperber et al., 2000).

After the Late Messinian Mediterranean LagoMare phase (sensu Stoica et al., 2016), the early Pliocene is characterized by a rapid restoration of full marine environmental conditions with deposition unconformity on the evaporites of white chalk (Trubi Formation) (Pedley and Grasso, 1992). The depositional environment of this sediment is bathyal as documented by the presence of psychrospheric and deep water ostracods immediately on the top of the Messinian facies (F.S., personal observation). This seems to show a rapid and abrupt sea level rise due to the abrupt enlargement of the channel between the Atlantic Ocean and the Mediterranean Sea.

The present contribution focuses on the LagoMare ostracod fauna coming from upper Messinian stratigraphic levels cropping out in some localities of eastern Sicily above the evaporitic facies (Figure 1). The aim of the study is the taxonomic analysis of ostracod species belonging to the Lago-Mare facies in a period just before the restoration of fully marine conditions (post evaporitic phase). Some levels attributable to Lago-Mare facies were previously analyzed in SE Sicily but only with regard to mollusc fauna (Di Geronimo et al., 1989). Today the acquired knowledge on ostracods in the present study adds up to those of Eraclea Minoa (Bonaduce and Sgarrella, 1999) and Pasquasia (Colalongo, 1967).

\section{GEOLOGICAL SETTING}

The upper Messinian sedimentary levels sampled for this study belong to two different paleogeographic contexts: the Villafranca Tirrena Basin and the north-western border of the Hyblean Plateau. 


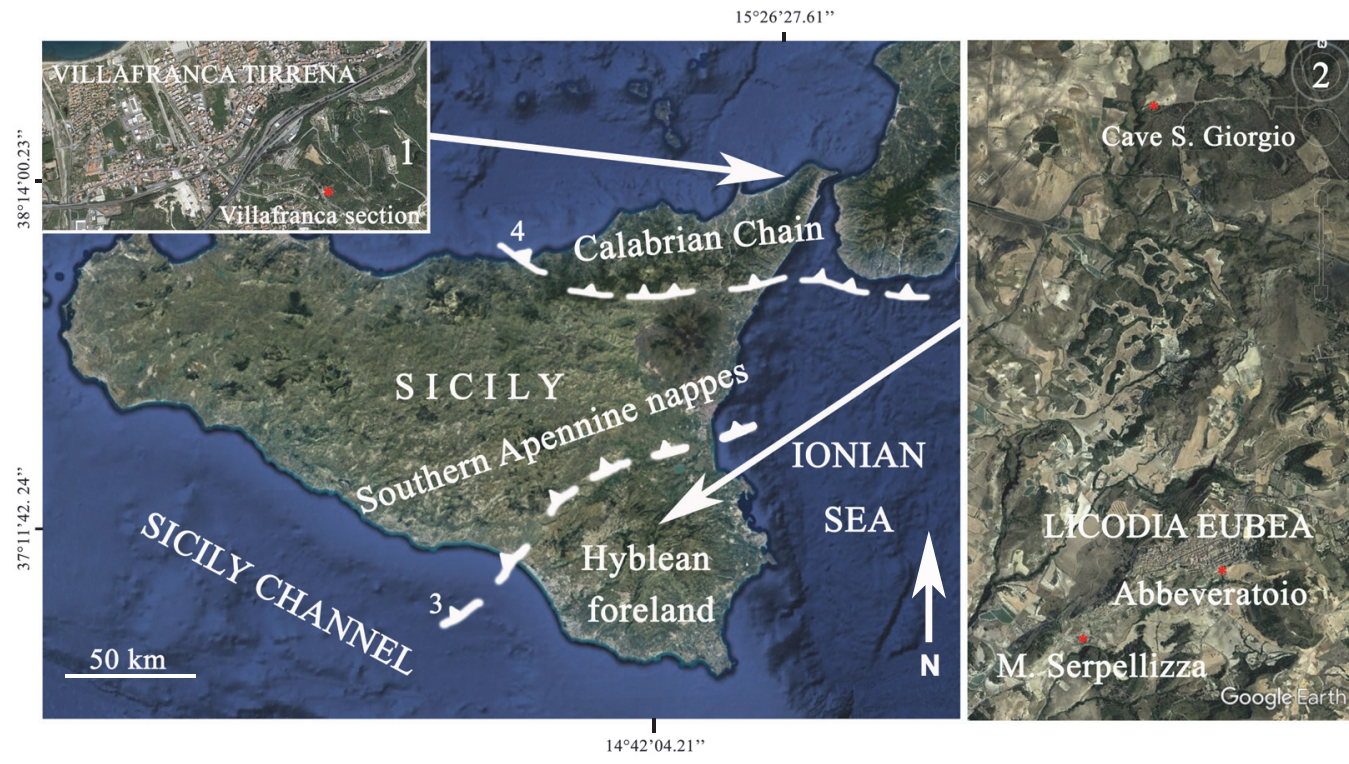

FIGURE 1. Geographical location of the sampling stations (red dots) in northeastern (1) and southeastern Sicily (2); and the external front of the Apenninic Chain (3) and overthrust of the Calabride Units (4). Some rights reserved: Imagery @ 2015 TerraMe-trics, Map Data @ 2015 Google. Note: The authors are the 'sole responsible' for the usage made of texts, illustrations (tables and drawings), photos and videos provided and used in their respective publications.

The Villafranca Tirrena Basin is situated in NE Sicily, along the Tyrrhenian coast (Figure 1.1). This area is structurally part of the Apennine-Maghrebian chain ("Aspromonte Unit" auct.), characterized by a metamorphic basement covered unconformably by a complicated series of Miocene and PlioPleistocene sediments with extremely variable thickness (from a few to tens of meters), frequent facies transitions, stratigraphic gaps and unconformities (Lentini et al., 1987). The sedimentary sequence started with polygenic conglomerates evolving laterally and upward to gray clayey marls with fine sand; these terms deposited during the early-middle Miocene. Upwards the Messinian sequence deposited, consisting of evaporitic carbonates (Calcare di Base), calcareous breccias and gypsum. During the post evaporitic, phase medium and coarse sands and breccias are deposited, called "Arenazzolo" (Mottura, 1871; Ogniben, 1957). The Pliocene Trubi Formation followed, evolving upwards to marls and sands. The sequence ended with the Pleistocene "blue clays" and calcarenites. The other upper Messinian sedimentary levels were sampled in three different localities ("Abbeveratoio", "Cave San Giorgio" and "Monte Serpellizza") in the surroundings of the village of Licodia Eubea (Figure 1.2).

Structurally, the area is a part of the Hyblean foreland, a prevalently calcareous plateau that occupies the SE sector of Sicily. The outcropping stratigraphic sequence is characterized by mainly carbonate sediments intercalated with subaerial and submarine volcanic products at various levels. The oldest layers consist of pelagic calcareous marls with ammonites and belemnites (Hybla Formation) assigned to the Lower Cretaceous. Cretaceous-Eocene white cherty limestones (Amerillo Formation) followed. The Mesozoic-Cenozoic boundary is marked by intraformational breccias, re-sedimentation and slumping deposits, which were the result of a strong synsedimentary tectonic activity (Lentini et al., 1987). Carbonate sediments of shelf environment deposited in the Cenozoic followed during the Oligocene-early Miocene interval by calcarenites and calcisiltites of the Ragusa Formation, locally including re-sedimented layers with Miogypsina sp. These layers were overlain in the middle Miocene by grey marls of the more pelagic Tellaro Formation (Romeo and Sciuto, 1987), containing a nautiloid cephalopod Aturia aturi (Basterot, 1825). During the Messinian Stage a series of sediments deposited, which document the Messinian Salinity Crisis.

These sediments include confined and discontinuous siliceous laminated sediments (Tripoli Formation), evaporitic limestones (Calcare di Base) and Gypsum, which were deposited in semiclosed synsedimentary tectonic basins, at the 
depth of 150-200 m (Pedley and Grasso, 1992). The Licodia Eubea gypsum has been interpreted as related to the "Primary Lower Gypsum" of the Central Sicily Basin (Di Geronimo et al., 1989; Pedley and Grasso, 1992; Roveri et al., 2006, 2008). Apparently paraconcordant post evaporitic upper Messinian sediments followed. They consisted of carbonate breccias, marls, sands and silts locally containing oligohaline to freshwater faunas (LagoMare facies). These facies are referred to as "Congeria strata" when constituted by marls containing oligohaline mollusc faunas (Di Geronimo et al., 1989; Pedley and Grasso, 1992), and "Arenazzolo" when consisting of reddish arkose containing brackish to fresh-water ostracods (Bonaduce and Sgarrella, 1999; Roveri et al., 2008; present paper). The succession is closed by lower Pliocene (Zanclean) remarkably thick white chalks, very rich in planktic foraminifers and nannofossils (Trubi Formation) representing the restoration of fully marine conditions. In the Licodia Eubea area, Pleistocene calcarenites and marls can be found on the top.

\section{MATERIAL AND METHODS}

\section{Sampling Sites}

Villafranca Tirrena section. The sampled layers crop out in the southern slope of the Guardiola hill along the road Galvaruso-Fondaco (38'14'02.42'N; $15^{\circ} 26^{\prime} 14.11^{\prime \prime} \mathrm{E} ; 43 \mathrm{~m}$ a.s.I.). The stratigraphic sequence analyzed (Figure 2) consists of $2 \mathrm{~m}$ of upper Messinian terrigenous medium and coarse sands and breccias (Arenazzolo) distributed in thick layers overlain by the lower Pliocene calcareous marls of the Trubi Formation. Four samples were taken from the upper Messinian levels and eight samples from the Trubi Formation.

Abbeveratoio section. This sampling station (Figure 3 ) is located a few dozen meters south of the Licodia Eubea village $\left(37^{\circ} 09^{\prime} 20.11^{\prime \prime} \mathrm{N} ; 14^{\circ} 42^{\prime} 33\right.$. 81 "E; $554 \mathrm{~m}$ a.s.I.). The stratigraphic sequence starts with $3 \mathrm{~m}$ of well-stratified gypsum crystals, followed, in apparent conformity, by a $50 \mathrm{~cm}$ thick layer of reddish sands and silty sands, known as "Arenazzolo". These two terms refer to the Messinian (Di Geronimo et al., 1989; inter alias). The lower Pliocene sedimentary sequence (Di Geronimo et al., 1989; inter alias) follows upwards in paraconformity. It consists of a $7 \mathrm{~m}$ thick sequence of predominantly white marls and limestone marls (Trubi chalk), containing a bivalve Neopycnodonte navicularis (Brocchi, 1814) and ichnofossils attrib- utable to Zoophycos sp. Four samples were taken from the Arenazzolo level and seven samples from the Trubi Formation.

Cave San Giorgio section. This sample station is located in the east side of the Mangalavite valley in the territory of Vizzini village $\left(37^{\circ} 11^{\prime} 43.07^{\prime \prime} \mathrm{N}\right.$; $14^{\circ} 42^{\prime} 04.90^{\prime \prime} \mathrm{E} ; 521 \mathrm{~m}$ a.s.I.). The studied sequence (Figure 4) consists of gypsum strata topped by about three meters of the upper Messinian white marls called "Congeria strata" (Di Geronimo et al., 1989), which are superimposed by three meters of subaerial basaltic lavas and, unconformably, by the lower Pliocene Trubi Formation. Several samples were taken from the Congeria strata, and from the lowest levels of the Trubi Formation.

Monte Serpellizza section. This section (Figure 5) is located on the southern slope of the Licodia Eubea hill $\left(37^{\circ} 08^{\prime} 53.71^{\prime \prime} \mathrm{N}\right.$; $14^{\circ} 41^{\prime} 38.81^{\prime \prime} \mathrm{E} ; 435 \mathrm{~m}$ a.s.I.). The studied sequence begins with several meters of gypsum covered concordantly by the white marl of the Trubi Formation. No post evaporitic levels were found at this locality; the lower portion of the Trubi Formation was sampled.

Methods

Samples were analyzed for the ostracod content; the most significant planktic and benthic foraminifers and calcareous nannofossils were also identified. From each sample, $250 \mathrm{~g}$ of a sediment were washed using diluted hydrogen-peroxide for disaggregation. They were subsequently sieved through standard sieves $(63 / 125 / 250 / 500 \mu \mathrm{m})$. Less than $250 \mu \mathrm{m}$ residuals were picked out completely and ostracods were investigated taxonomically in detail. From the $125 \mu \mathrm{m}$ sieve-residual, 0.2 $\mathrm{g} / \mathrm{samples}$ were picked and then quarted if necessary for foraminifers. The specimens were examined and measured under a stereomicroscope and photographed under LMU Tescan Vega II Scanning Electron Microscope of the Electronic Microscopy Laboratory, of the Earth Science Section (University of Catania). The specimens are housed in the Paleontological Museum of Catania University (PMC) with the following abbreviations: "OFS" = Ostracoda figured specimens and "Gt.FS" = Girogonite figured specimens.

\section{RESULTS}

\section{Biostratigraphic Remarks}

The calcareous nannofossil assemblages of Licodia Eubea and Villafranca Tirrena sections coming from the white chalks of the Trubi Formation, cropping above the Lago-Mare sedimentary 


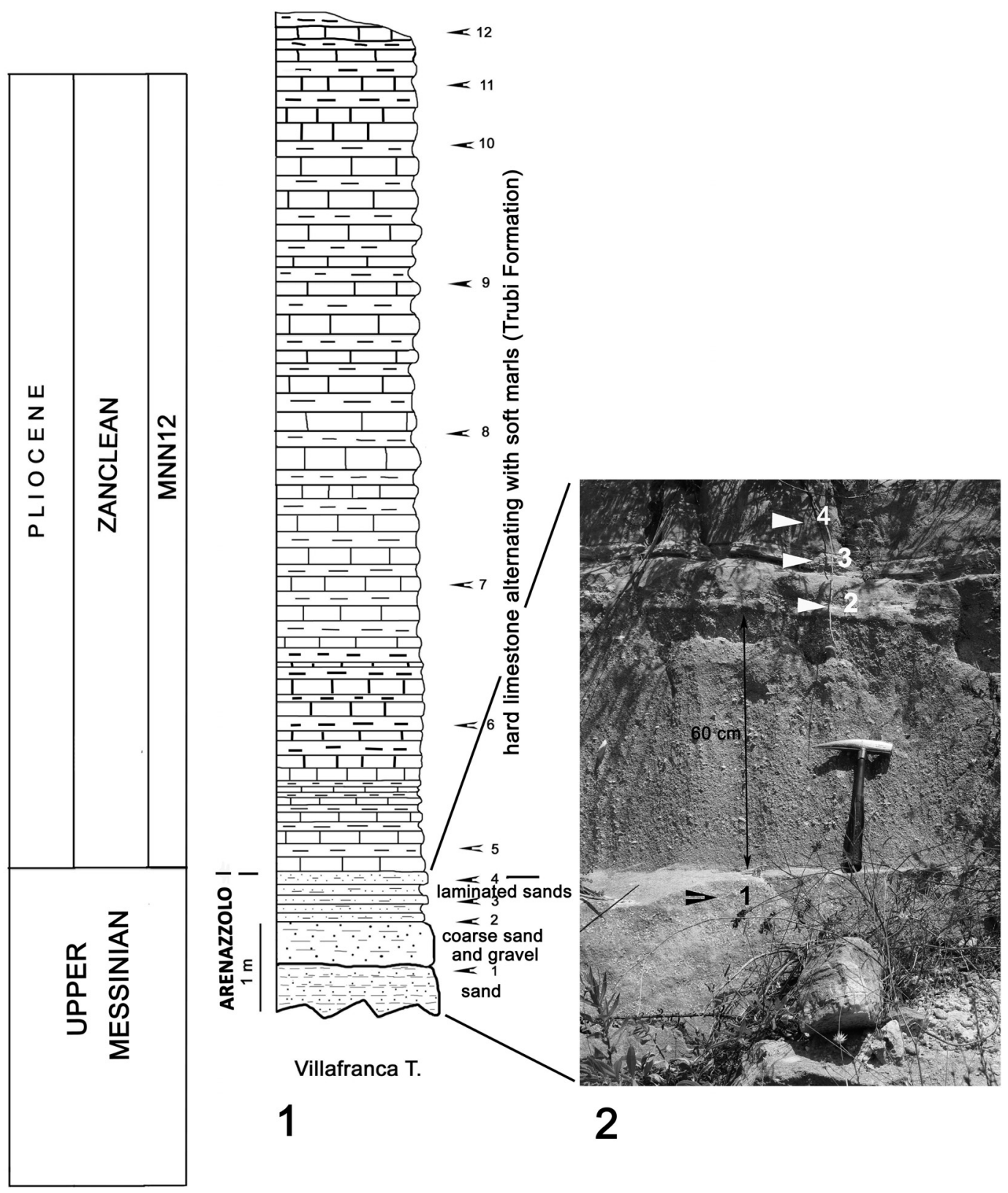

FIGURE 2. Stratigraphycal log (1) with the position and number of samples of the Villafranca Tirrena section (2).

facies, are rich and the specimens are well-preserved. The assemblages collected from both sections are similar to each other and allow to identify many important markers for the Messinian-Zanclean boundary and to define better the age of the lowermost portion of the Trubi Formation. Two key events, such as the occurrence of Ceratholithus acutus Gartner and Bukry, 1974 and the presence of Reticulofenestra zancleana Di Stefano and Sturiale, 2010 in the assemblages, allow to attribute the sediments of the Trubi Fomation, overlying the upper Messinian levels studied here, to the basal Zanclean: CNPL1 Zone sensu Backmann et al. (2012) or MNN 12 biozone sensu Martini (1971). It is noteworthy that the occurrence of $R$. zancleana, as a characteristic marker of the Reticulofenestra zancleana Interval Subzone MNN12a with the FO into the Cycle 1 ( $5.332 \mathrm{Ma}$ ) and the LCO at Cycle 7 (5.199 Ma), determines a better stratigraphic resolution, demonstrating its importance for the Medi- 

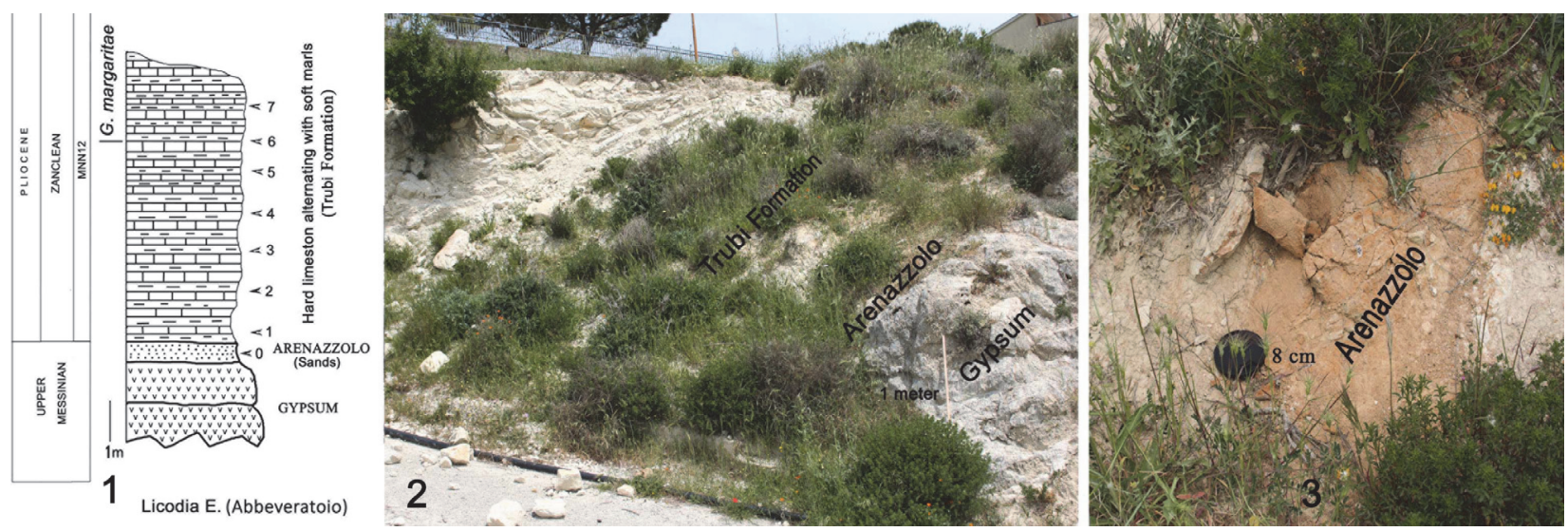

FIGURE 3. Stratigraphycal log (1) with the position and number of samples of the Abbeveratoio section (2) and particular of the Arenazzolo outcrop (3).

terranean biostratigraphy. Few specimens of Amaurolithus primus (Bukry and Percival, 1971) Gartner and Bukry, 1975, are also found in the same samples. In the surrounding area of Vallone Scorciavitelli, just north of Licodia Eubea, the Messinian succession is closed by basaltic lavas, whose magnetostratigraphy highlighted an inverse magnetization referable to the Messinian-Zanclean boundary (Grasso et al., 1983). The Villafranca Tirrena samples also contain rare, but well-preserved Scyphosphaera apsteinii Lohmann, 1902, Scyphosphaera piriformis Kamptner, 1955, and common Helicosphaera carteri (Wallich) Kamptner, 1954.
According to Grossi et al. (2011) the contemporary recovery of Cyprideis agrigentina Decima, 1964, Loxoconcha muelleri (Méhes, 1908), L. eichwaldi Livental, 1929, and Tyrrhenocythere pontica (Livental) in Agalarova et al., 1961, as it happens in the underlying Lago-Mare facies of Cave San Giorgio section, allows to attribute these levels to the upper part of the L. muelleri Zone (lower post evaporitic phase of the Messinian stage).

Since the base of the Trubi Formation is referable to an age within the base of MNN12 biozone (early Pliocene, Zanclean), the Lago-Mare facies sampled and analyzed here is referred to as the final part of the Messinian stage.
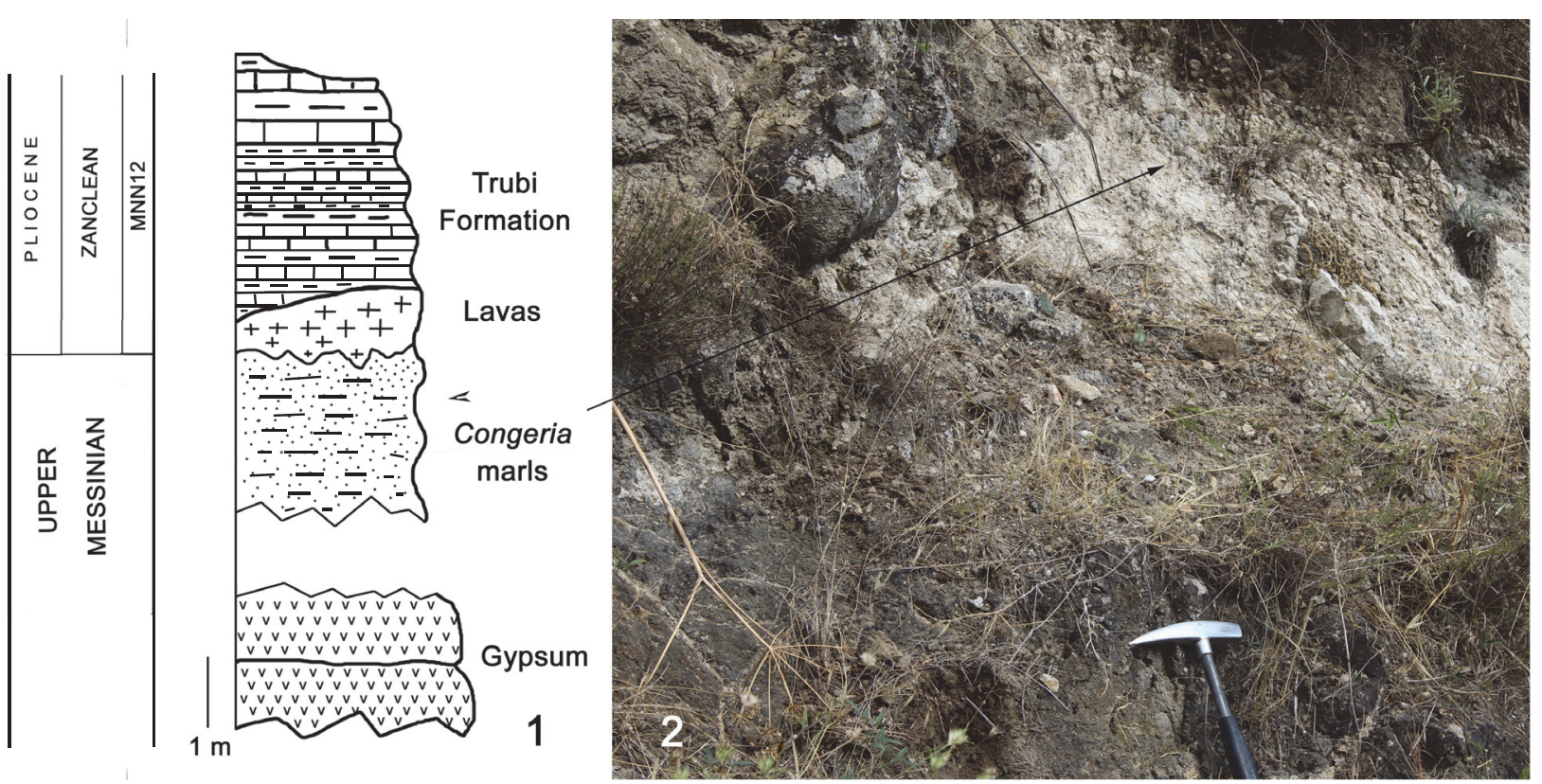

FIGURE 4. Stratigraphycal log (1) with the position and number of samples of the Cave San Giorgio section (2). 


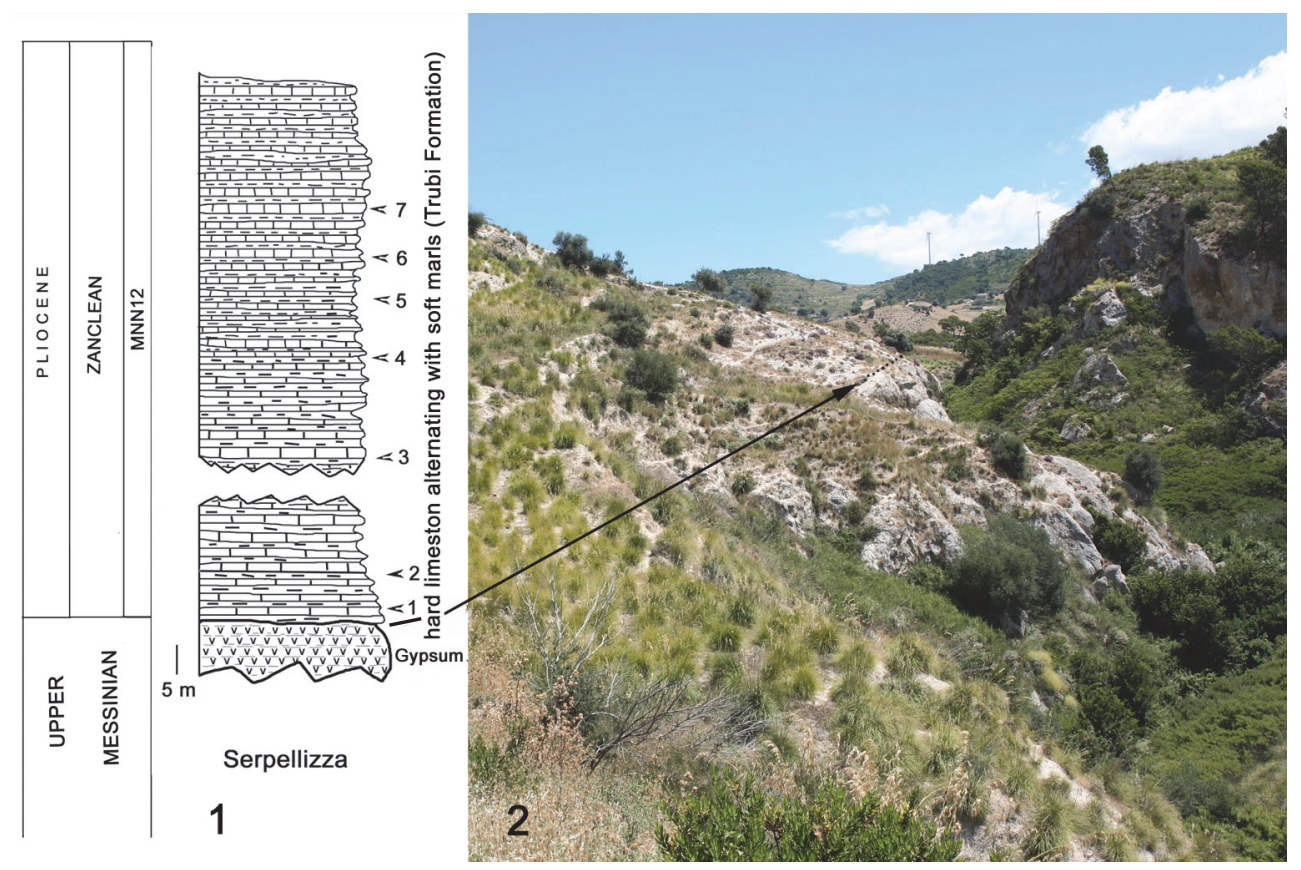

FIGURE 5. Stratigraphical log (1) with the position and number of samples of the Serpellizza section (2). The arrow indicates the boundary between the gypsum and the Trubi.

\section{Ostracod Faunas}

Villafranca Tirrena section. The ostracod fauna from the upper Messinian medium-coarse sand and gravel underlying the Trubi Formation is very poor and is represented only by species of the genus Cyprideis.

Abbeveratoio section. Some samples were taken from the "Arenazzolo" levels constituted by $50 \mathrm{~cm}$ of reddish sands and silty sands. The ostracod fauna is represented only by species of the genus Cyprideis and Tyrrhenocythere.

Cave San Giorgio section. The ostracod fauna taken from "Congeria strata" is slightly more abundant than other sampled stations and is represented by species belonging to the genus Cyprideis, Tyrrhenocythere and Loxoconcha.

Monte Serpellizza section. The gypsum strata are covered directly by the Zanclean Trubi Formation. There are no levels attributable to the upper Messinian Lago-Mare facies.

\section{SYSTEMATIC PALEONTOLOGY}

The species found in the post evaporitic sedimentary levels cropping out in the different sampling stations are listed systematically and commented on below.

Class OSTRACODA Latreille, 1806

Subclass PODOCOPA Sars, 1866

Order PODOCOPIDA Sars, 1866
Family HEMICYTHERIDAE Puri, 1953 Genus TYRRHENOCYTHERE Ruggieri, 1955

Type species. Tyrrhenocythere pignatii Ruggieri, 1955 by monotypy.

Tyrrhenocythere pontica (Livental) in Agalarova et al., 1961

Figure 6.1-3

1961 Cythereis pontica Livental; Agalarova, Kadyrova, and Kulijeva, p. 136, pl. 85, figs. 2, 3.

1979 Tyrrhenocythere pontica (Livental); Carbonnel, p. 109, pl. 2, fig. 17.

1999 Tyrrhenocythere pontica (Livental) in Agalarova, Kadyrova, and Kulijeva; Gliozzi, p. 201, pl. 2, figs. c-l, pl. 3, fig. d.

1999 Tyrrhenocythere pontica (Livental); Bonaduce and Sgarrella, pl. 1, fig. 9.

2007 Tyrrhenocythere pontica (Livental); Gliozzi, Ceci, Grossi, and Ligios, p. 331.

2008 Tyrrhenocythere pontica (Livental); Gliozzi and Grossi, p. 290.

2008

Tyrrhenocythere pontica (Livental); Bossio, Ciampalini, Colonese, Da Prato, Rafanelli, and Zanchetta, pl. 1, fig. 16.

The San Giorgio specimens although having more evident fossae are rather similar to that figured by Gliozzi (1999, pl. 2, fig. d); different height/ length ratio may indicate sexual dimorphism.

Since the Pontian (sensu Snel et al., 2006; Pipík, 2007) species of Tyrrhenocythere are widely 


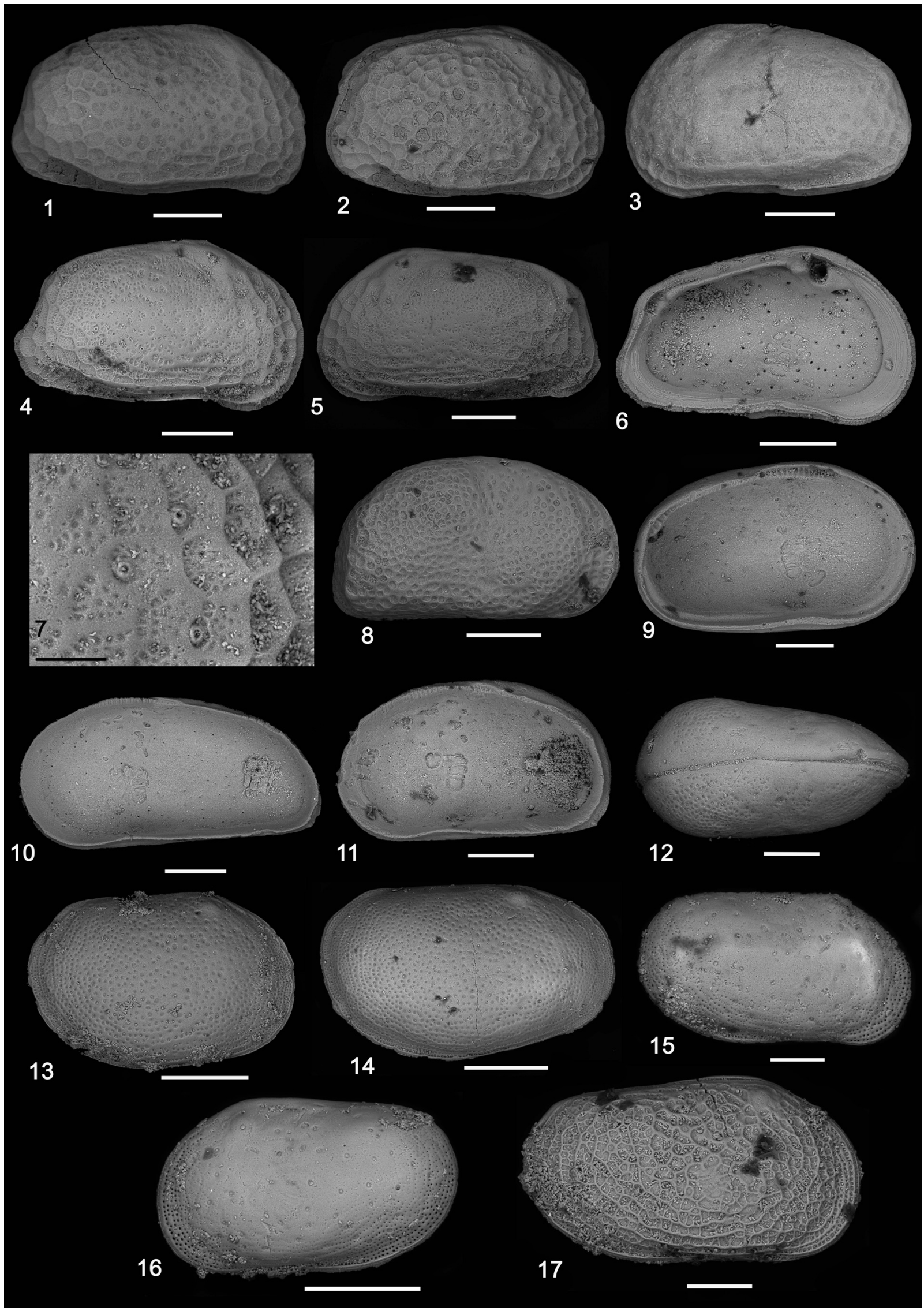


distributed in brackish and freshwater environments within basins of the Paleomediterranean and Paratethyan regions (Boomer et al., 1996; Pipík, 2007). After rapid radiation in the Pontian, the genus began to decline and today appears to be represented by only one species, $T$. amnicola (Sars, 1887) (Pipík, 2007), which occurs at different depths and in hypohaline and mesohaline waters (Gliozzi, 1999) in the Black Sea, the Caspian Sea (Aladin et al., 2000) and the Aral Sea (Opreanu, 2004). In particular, the genus Tyrrhenocythere is not reported from Italy during the early Messinian while it is reported from the Paratethyan region (Pannonian Basin, Dacian Basin). Afterwards the genus is reported both in Paratethyan region and in Italy during the late Messinian, thus witnessing its immigration from Paratethyan region to the Paleomediterranean area (Carbonnel, 1980; Pipík, 2007).

\section{Tyrrhenocythere pulcherrima sp. nov.} Figure 6.4-7

\section{zoobank.org/2D3ECA2A-4F00-432B-B488-772948153C46 \\ 2011 Aurila arborescens (Brady, 1865); Sciuto, p. 64, fig. 3. \\ 2015 Aurila arborescens (Brady, 1865); Sciuto, Rosso, Sanfilippo, and Maniscalco, p. 49, pl. 1, fig. L.}

Derivatio nominis. From the Latin word pulcherrima: very beautiful.

Type material. Three valves. Holotype: The right valve (length $=810 \mu \mathrm{m}$; height $=440 \mu \mathrm{m})$ PMC. $\mathrm{O}$ 20 H 19/5/2017 (Figure 6.4 and 6.7). Paratypes: Two left valves PMC. O 73-74 P 19/5/2017 (Figure 6.5 and 6.6).

Type locality. Cava San Giorgio in the east side of the Mangalavite valley (Tav. Vizzini, F. 645, IV, NO: $37^{\circ} 11^{\prime} 43.07^{\prime \prime} \mathrm{N}$; $14^{\circ} 42^{\prime} 04.90^{\prime \prime} \mathrm{E} ; 521 \mathrm{~m}$ a.s.I.) in upper Messinian white marls named "Congerie strata" (Di Geronimo et al., 1989) overlying the Messinian gypsum strata.

Stratigraphic range. Upper Messinian (lower part of the post evaporitic phase) to Zanclean. Other specimens have been found from lower Pleistocene shallow water sediments outcropping at Cartiera Mulino near Vittoria, southeast Sicily (Sciuto, 2011; Sciuto et al., 2015).

Other material. Some valves from lower Pleistocene shallow water sediments outcropping at Cartiera Mulino near Vittoria, southeast Sicily (Sciuto, 2011; Sciuto et al., 2015).

Diagnosis. The species is characterized by strong sub-trapezoidal carapace in lateral view with dense ornamentation constituted by polygonal muri and fossae.

Description. Carapace medium-sized, sub-rhomboidal in lateral view (Figure 6.4-7). Valves unequal, right valve slightly bigger than left. Anterior margin arched downwardly. Dorsal margin long and straight, posterior margin straight and angled. Caudal process small and arched. Ventral margin slightly sinuous, with a light oral convexity anteriorly, and regularly and steeply bending posteriorly. Outer surface ornamented by dense polygonal reticulation with well-marked muri, which delineate polygonal areas with another smaller and finer grid inside. Eye tubercles present. Normal pore canals simple, few and evenly distributed on the carapace.

Inner lamella: Anteriorly and postero-ventrally wide; there are a large anterior vestibulum and a narrower one in postero-ventral area (Figure 6.6). Marginal pore canals not visible.

Hinge: In the left valve is constituted by a straight groove parallel to the dorsal margin with, at the anterior and posterior extremities, two simple teeth and two sockets, one simple posteriorly and one double anteriorly (Figure 6.6); the right valve complementary. Muscle scars consisting of an

FIGURE 6 (left). Scanning electron microscope (SEM) photographs of Late Messinian "Lago-Mare" ostracods. 1-3, Tyrrhenocythere pontica (Livental, 1929) from Cave San Giorgio, PMC. OFS 30, right valve in lateral view (1); PMC. OFS 31, right valve in lateral view (2); and PMC. OFS 32, left valve in external lateral view (3). 4-7, Tyrrhenocythere pulcherrima sp. nov. from Cave San Giorgio, PMC. O 20 H 19/5/2017 (holotype), right valve in lateral view (4); PMC. O 73 P 19/5/2017 (paratype), left valve in lateral view (5); PMC. O 74 P 19/5/2017 (paratype), left valve in internal view

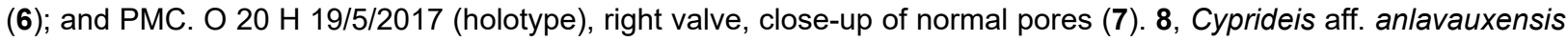
Carbonnel, 1979 from Cave San Giorgio, PMC. OFS 33, right valve in lateral view. 9, Cyprideis agrigentina Decima, 1964 from Cave San Giorgio, PMC. OFS 34, left valve in internal view. 10-12, Cyprideis ex C. torosa (Jones, 1850) group from Cave San Giorgio, PMC. OFS 35, right valve in internal view (10) and PMC. OFS 36, right valve in internal view (11); from Licodia Eubea, PMC. OFS 37, in dorsal view (12). 13-14, Loxoconcha eichwaldi Livental, 1929 from Cave San Giorgio, PMC. OFS 38, female, right valve in lateral view (13) and PMC. OFS 39, male, right valve in lateral view (14). 15-16, Loxoconcha muelleri (Méhes, 1908) from Cave San Giorgio, PMC. OFS 40, right valve in lateral view (15) and PMC. OFS 41, left valve in lateral view (16). 17, Loxoconcha n. sp. from Cave San Giorgio, PMC. OFS 42, right valve in lateral view. Scale bars equal $200 \mu \mathrm{m}$ except $7(50 \mu \mathrm{m})$ and $17(100 \mu \mathrm{m})$. 


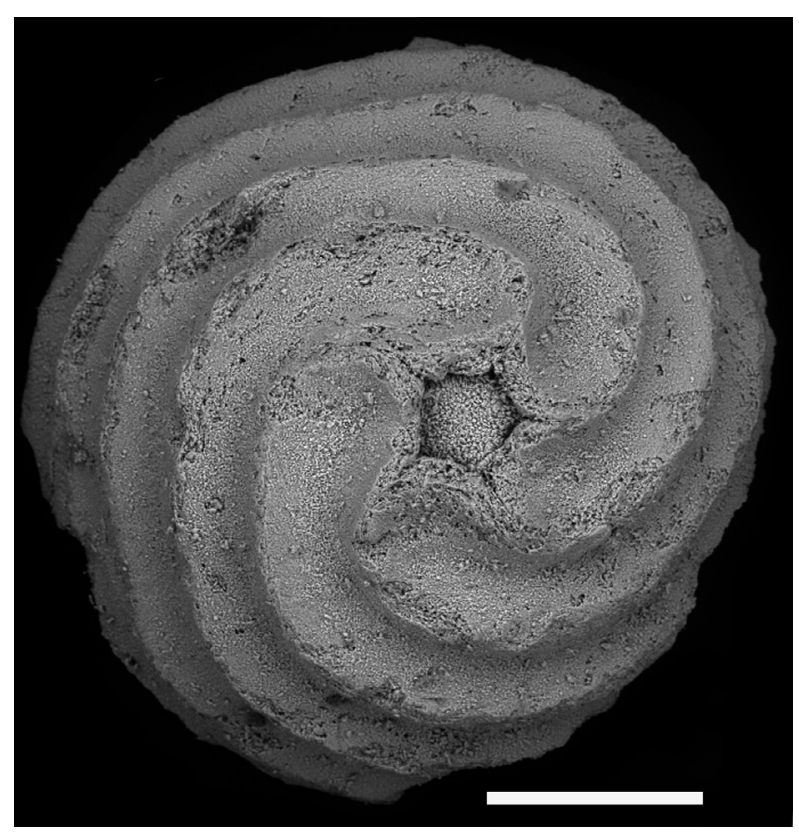

FIGURE 7. Scanning electron microscope (SEM) photographs of Chara hispida Linnaeus, 1753 from Cave San Giorgio, PMC. Gt.FS 48, basal view of gyrogonites. Scale bar equals $200 \mu \mathrm{m}$.

inclined row of four scars centrally with three anterior and four posterior scars (Figure 6. 6).

Remarks. The species described herein has been assigned to the genus Tyrrhenocythere Ruggieri, 1955 because of morphological features such as the general shape of the carapace, the type of hinge and the muscle scars. Tyrrhenocythere pulcherrima sp. nov. is easily distinguishable from congeners T. pignatii Ruggieri, 1955 and T. ruggierii Devoto, 1967 by dense ornamentation. It can also be distinguished from $T$. pontica (Livental) in Agalarova et al., 1961, which is very similar, because of the different trend of the primary polygonal grip and the absence of secondary grip.

The new species is rather similar to $T$. incerta Olteanu, in Olteanu and Vekua, 1989 (Figure 7); nevertheless the comparison between the valves of the two species seen internally shows obvious differences, most importantly, the shape of the outer edge. The ventral margin of $T$. pulcherrima sp. nov. is long and almost straight, that of $T$. incerta is short and sinuous with a very pronounced oral convexity. The postero-ventral margin in $T$. pulcherrima sp. nov. is straight and oblique, while that of $T$. incerta is rounded. Also on the external surface of the valves there are differences such as greater density of the secondary reticulation and the primary reticulation also pres- ent in the central part of the valve in T. pulcherrima sp. nov.

In the hinge area, the left valve of $T$. pulcherrima $\mathrm{sp}$. nov. shows a long ridge parallel to the dorsal margin; while in $T$. incerta the ridge is oblique with respect to the dorsal margin. The anterior groove is circular in T. pulcherrima sp. nov., almond shaped in T. incerta. The muscle scars form a single rounded group in T. pulcherrima sp. nov., while forming two elongated groups in $T$. incerta.

Tyrrhenocythere pulcherrima sp. nov. has been found in the upper Messinian sequence above the gypsum formation, associated with an ostracod fauna dominated by Cyprideis spp. Therefore, as all the other species of the genus it can be related to the shallow water late Messinian Lago-Mare facies.

\section{Tyrrhenocythere cf. T. ruggierii Devoto, 1967}

These specimens, coming from the red sands "Arenazzolo" cropping out at Licodia Eubea (Abbeveratoio), are very similar to those figured by Stoica et al. (2016, pl. 3, figures 5-9). Compared to specimens described by Devoto in Colacicchi et al. (1967, figures 5-8) those of Licodia Eubea are not perfectly smooth.

This species is known since the upper Messinian from Sicily (Bonaduce and Sgarrella, 1999), Le Vicenne (Abruzzo, Italy) (Devoto in Colacicchi et al., 1967; Gliozzi, 1999), the Vera Basin (Spain) (Stoica et al., 2016), and since the Pontian from the Paratethys region (Olteanu, 1982).

Family CYTHERIDEIDAE Sars, 1925 Genus CYPRIDEIS Jones, 1857

Type species. Candona torosa Jones, 1850 by subsequent designation of Jones (1857).

\section{Cyprideis anlavauxensis Carbonnel, 1979} Figure 6.8

1979 Cyprideis anlavauxensis; Carbonnel, p. 112, pl. 1, fig. 8, pl. 2, figs. 10, 11.

2006 Cyprideis anlavauxensis; Bassetti, Miculan, and Sierro, p. 287.

2007 Cyprideis anlavauxensis Carbonnel; Rouchy, Caruso, Pierre, Blanc-Valleron, and Bassetti, pl. IV, figs. 5, 6 .

2007 Cyprideis anlavauxensis Carbonnel; Gliozzi, Ceci, Grossi, and Ligios, p. 331.

2008 Cyprideis anlavauxensis Carbonnel; Gliozzi and Grossi, p. 290.

2012 Cyprideis anlavauxensis Carbonnel; Ligios and Gliozzi, p. 180, pl. 2, figs. 1-6.

The specimens, which come from Cave San Giorgio, are similar to Cyprideis anlavauxensis 
Carbonnel figured by Cosentino et al. (2007, figure 5.4) and Ligios and Gliozzi (2012, pl. 2. figures 1-6) especially for the external ornamentation and to Cyprideis aff. tuberculata figured Gliozzi (1999, pl. 4, figure g); nevertheless the foveolae are wider and, the valve outline, especially in the posterior margin, is different: almost straight in the Cava San Giorgio specimen, arcuate in the other case. This species, which is reported for the first time in Sicily, is widespread in the Messinian post evaporitic facies of Lago-Mare in Mediterranean region (Italy, France, Spain and Algeria) (Carbonnel, 1979; Gliozzi et al., 2007).

Cyprideis agrigentina Decima, 1964

Figure 6.9

1964 Cyprideis pannonica agrigentina; Decima, pp. 108-111, pl. 29, figs. 4-8, pl. 30, figs. 110 , pl. 31 , fig. 1.2 , pl. 37 , figs. $16-21$.

1964 Cyprideis pannonica pseudoagrigentina; Decima, pp. 111-113, pl. 31, figs. 3-7, pl. 32, figs. $1-2$, pl. 38 , figs. 1-2.

1978 Cyprideis pannonica (Méhes); Benson, p. 780, pl. 2, figs. 4-8.

1999 Cyprideis "agrigentina” Decima; Bonaduce and Sgarrella, pp. 84-86, pl. 1, fig. 1.

2007 Cyprideis agrigentina Decima; Rouchy, Caruso, Pierre, Blanc-Valleron, and Bassetti, pp. 392-393, 400, 407, 410-411, pl. 4, figs. 1 2.

2008 Cyprideis agrigentina Decima; Gross, Minati, Danielopol, and Piller, pp. 133, 135, 137140.

2008 Cyprideis agrigentina Decima; Trenkwalder, Violanti, D'Atri, Lozar, De la Pierre, and Irace, p. 94.

According to Gliozzi (1999) the specific attribution of Cyprideis is rather complex. Indeed, the morphological characters of the carapace can be too diverse to justify the adoption of the term Cyprideis ex gr. pannonica by Gross et al. (2008) to indicate rather small and nearly smooth specimens of the genus found in upper Sarmatian and lower Pannonian sediments of the Central Paratethys. This character is so distinct that Ligios and Gliozzi (2012) still proposes to create the " $C$. torosa group", that includes species similar to each other as C. agrigentina Decima, 1964, C. ruggierii Decima, 1964, C. torosa (Jones, 1850), and in part $C$. crotonensis Decima, 1964 and C. calabra Decima, 1964 (Ligios and Gliozzi, 2012).

In this work we have relied not only on the general outline, but also on the internal characters of the carapace and particularly on muscle scars, hinge and duplicature. The specimen figured in
Figure 6.9 is very similar to C. pannonica pannonica (Méhes, 1908) figured by Decima (1964, pl. 26, fig. 9). Nevertheless, Krstc (1968) excludes in the Mediterranean area the presence of C. pannonica and C. tuberculata and afterwards, Ligios and Gliozzi (2012) compared the specimens of C. pannonica in the Decima collection with $C$. pannonica from Austria, showed that the specimens coming from Sicily were referable to $C$. agrigentina.

This species is widespread in all the brackish Mediterranean domain during the "Lago-Mare" phase of the Messinian Salinity Crisis, from the end of the evaporitic phase (about 5.6 Ma) to the Messinian-Zanclean boundary (5.33 Ma) (Cosentino et al., 2007; Gross et al., 2008; Guerra-Merchán et al., 2010; Cipollari et al., 2012). It seems to occur more frequently in the mesohaline-high mesohaline facies, where it made up oligotypic assemblages together with Ammonia tepida (Bonaduce and Sgarrella, 1999; Grossi and Gennari, 2008; Guerra-Merchán et al., 2010), while in the oligomesohaline environment it seems to be vicariant with Cyprideis anlavauxensis (Grossi and Gennari, 2008). This species is reported from the Messinian of Eraclea Minoa (Decima, 1964), the upper Miocene (Pannonian Stage) of the northern Vienna Basin (Kováč et al.,1998), the upper Miocene of eastern Anatolia (Nazik et al., 2008), Pliocene of Almeria (Addicott et al., 1978), the upper Miocene (Sarmatian) of Thrace (Turkey), the lower Sarmatian of Romania (Radu and Stoica, 2005), the upper Miocene deposits of Anatolia (Şafak et al., 1999), and the early Pannonian of Hungary (Kollmann 1960). The majority of Cyprideis species live in brackish (meso-brachyhaline), euryhaline, mainly mesohaline (5-18\%o) environments but also oligohaline and hyperhaline (Gross, 2004, inter alias).

\section{Cyprideis ex C. torosa (Jones, 1850) group}

Figure 6.10-12

1964 Cyprideis torosa (Jones); Decima, pl. 11, figs. 3-8c, pl. 12, figs.1-8d, pl. 15, figs. 11-15.

2002 Cyprideis torosa (Jones, 1850); Wouters, pl. 3, figs. 1a-4d.

2005 Cyprideis torosa (Jones, 1850); MatzkeKarasz and Witt, pl. 3, figs. 8-11.

2007 Cyprideis torosa (Jones, 1850); Medley, Tibert, Patterson, Allen, Greer, and Colin, pl. 1, fig. e.

2012 Cyprideis torosa (Jones, 1850); LucenaMoya, Abraín, Pardo, Hermida and Domínguez, p. 6.

2011 Cyprideis torosa; Frenzel, Schulze, Pint, Boomer, and Feike, p. 59. 
2013 Cyprideis torosa (Jones, 1850); Valls, Rued, and Mesquita-Joanes, fig 3, G-I.

2015 Cyprideis torosa (Jones, 1850); Altınsaçlı, Altınsaçlı, and Paçal, p. 379.

2015 Cyprideis torosa (Jones, 1850); Schornikov, pl. 1, figs. 15-18.

2016 Cyprideis torosa (Jones, 1850); Bejaoui, Sciuto, Karoui-Yaakoub, Reitano, and AliNebiha, fig. 7, G-I.

2016 Cyprideis torosa (Jones); van Baak, Stoica, Grothe, Aliyeva, and Krijgsman, figs. 4, 18.

According to Ligios and Gliozzi (2012), the high similarity of $C$. agrigentina, C. ruggierii, $C$. torosa, and in part C. crotonensis and C. calabra, probably linked to tight phylogenetic relationships, suggests to us to include them in a comprehensive informal "C. torosa group". Also Wouters (2016) confirms that Cyprideis torosa Jones, 1850 is a single, highly variable, polymorphic and widely distributed species, with locally different populations.

This group includes euryhaline and eurythermal species that can live from freshwater to hypersaline water (sebkha) (Athersuch et al., 1989; Boomer et al., 1996). It has been reported from western and southern Europe, i.e., Mediterranean coasts, including Mediterranean Isles, and the Atlantic coasts of West and Northwest Europe. The species is also known from North Africa (Bejaoui et al., 2016), Eurasia, Central and Southwest Asia, (the Black Sea, Caspian Sea, Lake Aral and Lake Issyk Kul), and China (Wouters, 2002). It was also found in hypersaline environment at Santa Pola, a coastal salt marsh of the Western Mediterranean (Mezquita et al., 2011), in brackish estuaries and lagoons of mainland Portugal (Cabral et al., 2016) and in coastal mesohaline lagoons in Turkey (Altinsaçli et al., 2015). Fossil specimens are reported from the Miocene to Recent (Meisch, 2000). Cyprideis torosa is indicated as Paratethyan species (Matzke-Karasz and Witt, 2005).

Family LOXOCONCHIDAE Sars, 1925

Genus LOXOCONCHA Sars, 1866

Type species. Cythere rhomboidea Fisher, 1855 by subsequent designation of Brady and Norman (1889).

Loxoconcha eichwaldi Livental, 1929

\section{Figure 6.13-14}

1929 Loxoconcha eichwaldi; Livental, p. 34, pl. 1, figs. $42,43$.

1978 Loxoconcha eichwaldi Livental, 1929; Olteanu, p. 1020, pl. 7, fig. 2.

1979 Loxoconcha eichwaldi Livental, 1929; Carbonnel, p. 114, pl. 1, fig. 4.
1999

Loxoconcha eichwaldi Livental, 1929;

Gliozzi, p. 204, pl. 1, fig. d.

2001 Loxoconcha eichwaldi Livental, 1929; Tunoğlu, pl. 1, figs. 14, 15.

2007 Loxoconcha eichwaldi Livental; Gliozzi, Ceci, Grossi, and Ligios, p. 331.

2008 Loxoconcha eichwaldi Livental; Gliozzi and Grossi, p. 290.

2008 Loxoconcha eichwaldi; Bossio, Ciampalini, Colonese, Da Prato, Rafanelli, and Zanchetta, tav. 1, fig. 13.

2008 Loxoconcha eichwaldii Livental, 1929; Grossi and Gennari, fig. 4c.

2008 Loxoconcha eichwaldi; Trenkwalder, Violanti, D'Atri, Lozar, De la Pierre, and Irace, p. 94.

2016 Loxoconcha eichwaldi Livental, 1929; Stoica, Krijgsman, Fortuin, and Gliozzi, pl. 6, figs. 10-17.

2016 Loxoconcha eichwaldi Livental; van Baak, Stoica, Grothe, Aliyeva, and Krijgsman, figs. 4, 13-14.

Loxoconcha eichwaldi is widespread in the Pliocene, in the Pontian (Gliozzi, 1999; inter alias) and in the Pannonian (Krstić, 1972) of the Parathethyan region. In the Tethyan region it is reported from the upper Messinian of Corsica, Italy, and France (Carbonnel, 1979). The figured specimen comes from the upper Messinian Congeria strata of Cave San Giorgio. This species, which was found at Eraclea Minoa by Grossi et al. (2015), is reported for the first time from the southeastern Sicily.

Loxoconcha muelleri (Méhes, 1908)

Figure 6.15-16

1908 Cythereis mülleri Méhes; p. 562, pl. 8, figs, 15-18, pl. 9, figs. 1-4.

1929 Loxoconcha mülleri (Méhes, 1908); Zalanyi, p. 168 , pl. 36, figs a-d, pl. 37, figs. a-b.

1979 Loxoconcha mülleri (Méhes, 1908); Carbonnel, p. 116, pl. 1, figs. 6, 7, 12.

1998 Loxoconcha muelleri (Méhes, 1908); Kováč, Barath, Kovačova-Slamkova, Pipík, Hlavaty, and Hudačkova, pl. 4, fig. 1.

2007 Loxoconcha muelleri (Méhes, 1908); Faranda, Gliozzi, and Ligios, fig. 3(8).

2007 Loxoconcha muelleri (Méhes, 1908); Gliozzi, Ceci, Grossi, and Ligios, p. 331.

2007 Loxoconcha muelleri (Méhes, 1908); Rouchy, Caruso, Pierre, Blanc-Valleron, and Bassetti, pl. 5, fig. 8.

2008 Loxoconcha muelleri; Bossio, Ciampalini, Colonese, Da Prato, Rafanelli, and Zanchetta, pl. 1, fig. 12. 
2008 Loxoconcha mülleri (Méhes, 1908); Grossi and Gennari, fig. 4b.

2008 Loxoconcha muelleri; Trenkwalder, Violanti, D'Atri, Lozar, De la Pierre, and Irace, p. 94.

2011 Loxoconcha mülleri (Méhes, 1908); Grossi, Gliozzi, and Cosentino, p. 68.

2016

Loxoconcha muelleri (Méhes, 1908); Stoica, Krijgsman, Fortuin, and Gliozzi, pl. 6, figs. 19.

Loxoconcha muelleri and L. eichwaldi are Paratethyan species, which were widespread in the Mediterranean area during the Lago-Mare event (Faranda et al., 2007). Particularly L. muelleri is reported from the post evaporitic Adana Basin (Turkey) (Faranda et al., 2013) from the upper Messinian of Montepetra (Italy) (Grossi and Gennari, 2008), France and Corsica (Carbonnel, 1979) and Algeria (Rouchy et al., 2007).

According to Grossi et al. (2011), in the Mediterranean area the $L$. muelleri zone comprises an interval zone of between the FO of $L$. muelleri and the FO of the Paratethyan ostracod Loxocorniculina djaffarovi (Suzin, 1956). Within this interval the ostracod association is scarce and oligotypic and formed mainly of L.muelleri and C. agrigentina. Only in the upper part of the L. muelleri Zone the association becomes richer and also includes $L$. eichwaldi and T. pontica.

This species, which was found at Eraclea Minoa by Grossi et al. (2015), is reported for the first time from southeastern Sicily.

\section{Loxoconcha n. sp.}

Figure 6.17

Large size Loxoconcha (length $=535 \mu \mathrm{m}$, height $=290 \mu \mathrm{m}$ ), subtrapezoidal in lateral view. Valve ornamented with a dense reticulation consisting of polygonal muri and irregular fossae. Anterior and posterior marginal areas are covered by regular little fossae aligned to the margins. Although showing some resemblance with Loxocauda limata Schweyer or with Loxoconchissa reticulata Faranda et al., 2007, the species is currently assigned to the genus Loxoconcha. Since this species is represented by only one specimen, we have left the species denomination in open nomenclature. The figured specimen comes from the Cave San Giorgio sampling station. Repository numbers of the figured specimens are PMC. OFS 30-47.

\section{DISCUSSION}

The ostracod fauna found in the different sections analyzed in the present work has oligotypic character and is certainly comparable, both at genus and species level, with the Lago-Mare ostracods associations reported by many authors for other localities of the Paleomediterranean Basin (Gliozzi et al., 2007, inter alias). According to these authors, the paleogeographical distribution of the upper Messinian Lago-Mare ostracod species studied, i.e., Loxoconcha muelleri, L. eichwaldi, Tyrrhenocythere pontica, T. ruggierii, Cyprideis pannonica, C. anlavauxensis and C. torosa allow to be considered them as Paratethyan affinity species, or rather, species that during the post evaporitic phase spread from the eastern region (Paratethys) to the western region (Paleomediterranean). This phenomenon was favored essentially by the presence of special hydrological conditions in the Paleomediterranean area (large and shallow water basins in connection with each other and with the large waterways of the Paratethyan region) (Gliozzi et al., 2007; Olteanu and Jipa, 2006).

During the post evaporitic interval of the upper Messinian in East Sicily (Di Geronimo et al., 1989; Pedley and Grasso, 1992), as well as in other basins of the Mediterranean area (Rouchy et al., 2001; Rouchy and Caruso, 2006, inter alias), these basins, were formed above the evaporitic and preevaporitic substratum, because of the intense tectonic activity, that bent or broke it, giving rise to synclinals or grabens. In this thin tectonics basins, terrigenous sediments, which contained a brackish to fresh water ostracod fauna (Lago-Mare facies), were deposited. The shallow character of these basins is also witnessed by the finding of charophyte gyrogonites, among which, the best preserved are referable Chara hispida Linnaeus, 1753 (Soulié-Märsche and García, 2015) (Figure 7; repository number PMC. Gt.FS 48). Chara hispida lives in oligotrophic, freshwater shallow lake environments, peatland, mud-calcareous gyttja; it can occasionally be found in brackish waters. Therefore, it may be characterized as tollerant to salinity at a depth from about $0.5 \mathrm{~m}$ to about $3.5 \mathrm{~m}$ (Barinova et al., 2014 and references therein). The two different facies identified in the Licodia Eubea area, namely the arkosic sands "Arenazzolo" in the Abbeveratoio section and the marls of "Congeria strata" in the Cave San Giorgio section, correspond to two contiguous environments where salinity plays a decisive role in the selection of the species found. The "Arenazzolo sands", where only the genera Tyrrhenocythere and Cyprideis were found, represented a sedimentary facies deposited in a hyposaline or lacustrine-fluvial envi- 
ronment. The marls of Congeria strata, where, in addition to the previous genera, was found also the genus Loxoconcha, corresponded to a sedimentary facies deposited in a shallow water marinetransitional environment (internal lagoon) characterized by salty, brackish oligohaline water, with the addition of fluvial lacustrine water. This conclusion can be confirmed by the presence of Hydrobiidae, Thiaridae and Limnocardiidae to which the oligohaline genera Neritina, Melanopsis and Dreissena can be added (Di Geronimo et al., 1989). Above the sedimentary Lago-Mare facies, or directly on the gypsum strata, several tens of meters of the lower Pliocene white chalks (Trubi Formation), which represent the rapid return to the normal marine sedimentation, crop out in apparent concordance.

\section{ACKNOWLEDGMENTS}

The authors are grateful to the Handling Editor M. Hyzny and to the anonymous referees for the suggestions on the manuscript. Special thanks are due also to A. Viola (Electronic microscopy laboratory, Earth Science Section, Catania University) for SEM assistance. Palaeoecological Research Group contribution n. 433.

\section{REFERENCES}

Addicott, W.O., Snavely, P.D. Jr., Bukry, D., and Poore, R.Z. 1978. Neogene stratigraphy and paleontology of southern Almeria province, Spain: An overview. Geological Survey Bulletin, 1454:1-49.

Agalarova, D.A., Kadyrova Z.K., and Kulijeva, S.A. 1961. [Ostracoda from Pliocene and Post Pliocene Deposits of Azerbaijan, Baku]. Azerbaijan State Publisher, Baku. p. 420. (In Russian).

Aladin, N.V., Plotnikov, I.S., and Zhamoida, V. 2000. Palaeolimnology and palaeosalinty of the Aral Sea during the Holocene as indicated by ostracod deposits. Verhandlungen des Internationalen Verein Limnologie, 27:2605-2608. https://doi.org/10.1080/ 03680770.1998.11898135

Altınsaçlı, S., Altınsaçlı, S., and Paçal, F.P. 2015. Diversity, species composition and habitat preferences of Ostracoda (Crustacea) in seven karstic springs of varying salinity in Milas (Muğla, Turkey). International Journal of Fisheries and Aquatic Studies, 3:374-390. https:// doi.org/10.1515/ohs-2015-0020

Athersuch, J., Horne, D.J., and Whittaker, J.E. 1989. Marine and brackish water ostracods, p. 1343. In Kermack, D.M. and Barnes, R.S.K. (eds.), Synopses of the British Fauna. The Linnean Society of London, London. https://doi.org/10.1017/s0025315400059178

Backman, J., Raffi, I., Rio, D., Fornaciari, E., and Pälike, H. 2012. Biozonation and biochronology of Miocene through Pleistocene calcareous nannofossils from low and middle latitudes. Newsletters on Stratigraphy, 45(3):221-244. https://doi.org/10.1127/0078-0421/2012/0022

Barinova, S., Romanov, R., and Solak, C.N. 2014. New Record of Chara hispida (L.) Hartm. (Streptophyta: Charophyceae, Charales) from the Işıklı Lake (Turkey) and Critical Checklist of Turkish Charophytes. Natural Resources and Conservation, 2:33-42.

Bassetti, M., Miculan, P., and Sierro, F.J. 2006. Evolution of depositional environments after the end of Messinian Salinity Crisis in Nijar Basin (SE Betic Cordillera). Sedimentary Geology, 188-189:279-295. https://doi.org/10.1016/j.sedgeo.2006.03.009

Basterot, B. 1825. Description géologique du bassin tertiaire du S.O. de la France. Mémoire de la Société d' Histoire Naturelle 11. J. Tastu, Paris.

Bejaoui, S., Sciuto, F., Karoui-Yaakoub, N., Reitano, A., and Ali Nebiha, B.H. 2016. Pleistocene microfauna evolution along the southern side of the Bizerte Lake (Sidi Mansour section, northeast Tunisia): Palaeoenvironmental interpretation. Annales de Paléontologie, 102:151159. https://doi.org/10.1016/j.annpal.2016.08.001

Benson, R.H. 1978. The paleoecology of the ostracodes of DSDP Leg 42A. Initial Reports of Deep Sea Drilling Project, 42:777-787. https://doi.org/10.2973/dsdp.proc.42-1.135.1978

Bonaduce, G. and Sgarrella, F. 1999. Paleoecological interpretation of the latest Messinian sediments from southern Sicily (Italy). Memorie della Società Geologica Italiana, 54:83-91.

Boomer, I., Whatley, R., and Aladin, N.V. 1996. Aral Sea Ostracoda as environmental indicators. Lethaia, 29:77-85. https://doi.org/10.1111/j.1502-3931.1996.tb01840.x 
Bossio, A., Ciampalini, A., Colonese, A.C., Da Prato, S., Rafanelli, A., and Zanchetta, G. 2008. Nuovi dati sulle successioni del sottosuolo di Livorno. Atti della Società Toscana di Scienze Naturali, Memorie Serie A, 113:13-24.

Brady, G.S. 1865. On undescribed fossil Entomostraca from the Brick-Earth of the Nar. Annals and Magazine of Natural History, 16(3):189-191.

Brady, G.S. and Norman, A.M. 1889. A monograph of the marine and freshwater Ostracoda of the North Atlantic and of Northwestern Europe. Section 1, Podocopa. Scientific Transactions of the Royal Dublin Society, Series 2, 4:63-270.

Brocchi, G.V. 1814. Conchiologia fossile subappennina, con osservazioni sugli Appennini e sul suolo adiacente. Dalla Stamperia Reale, Milano.

Cabral, M.C., Fatela, F., Lopes V., Freitas, M.C., and Andrade, C. 2016. Cyprideis torosa (Jones, 1850) in mainland Portugal: What do we know? Journal of Micropalaeontology, 36(1):94-112. https://doi.org/10.1144/jmpaleo2015-031

Carbonnel, G. 1979. La zone a Loxoconcha djaffarovi Schneider (Ostracoda Miocéne supèrieur) ou le Messinien de la vallée du Rhône. Revue de Micropalèontologie, 21:106-118.

Carbonnel, G. 1980. L'ostracofaune du Messinien: Une preuve de la vidange de la Paratéthys. Géologie Méditerranéenne, 78:19-24.

Colacicchi, R., Devoto, G., and Praturlon, A. 1967. Depositi messiniani al bordo orientale del Fucino e descrizione di Tyrrhenocythere ruggierii Devoto, nuova specie di ostracode. Bollettino della Società Geologica Italiana, 86:21-37.

Caruso, A., Pierre, C., Blanc-Valleron, M.-M., and Rouchy, J.M. 2015. Carbonate deposition and diagenesis in evaporitic environments: The evaporative and sulphur-bearing limestones during the settlement of the Messinian Salinity Crisis in Sicily and Calabria. Palaeogeography, Palaeoclimatology, Palaeoecology, 429:136-162. https://doi.org/10.1016/ j.palaeo.2015.03.035

Colacicchi, Devoto, G., and Praturlon, A. 1967. Depositi messiniani oligoalini al bordo orientale del Fucino e descrizione di Tyrrhenocythere ruggierii Devoto, nuova specie di ostracode. Bollettino della Società Geologica Italiana, 86:21-37.

Colalongo, M.L. 1967. Ostracodi del neostratotipo del Messiniano. Giornale di Geologia, 2:6772.

Cosentino, D., Gliozzi, E., and Pipponzi, G. 2007. The late Messinian Lago-Mare episode in the Mediterranean Basin: preliminary report on the occurrence of Paratethyan ostracod fauna from central Crete (Greece). Geobios, 40:339-349. https://doi.org/10.1016/ j.geobios.2007.01.001

Decima, A. 1964. Ostracodi del gen. Cyprideis Jones del Neogene e del Quaternario italiani. Palaeontographia Italica, 57:81-133.

Di Geronimo, I., Esu, D., and Grasso, M. 1989. Gli strati a "congerie" del Messiniano superiore del margine nord occidentale ibleo. Caratteristiche faunistiche e possibili implicazioni palegeografiche e paleoclimatiche. Atti Accademia Peloritana dei Pericolanti, 68(1):129-150

Di Stefano, A. and Sturiale, G. 2010. Refinements of calcareous biostratigraphy at the Miocene/ Pliocene Boundary in the Mediterranean region. Geobios, 43:5-20. https://doi.org/10.1016/ j.geobios.2009.06.007

Faranda, C., Gliozzi, E., Cipollari, P., Grossi, F., Darbaş, G., Gürbüz, K., Nazik, A., Gennari, R., and Cosentino, D. 2013. Messinian paleoenvironmental changes in the easternmost Mediterranean Basin: Adana Basin, southern Turkey. Turkish Journal of Earth Science, 22:839-863.

Faranda, C., Gliozzi, E., and Ligios, S. 2007. Late Miocene brackish Loxoconchidae (Crustacea, Ostracoda) from Italy. Geobios, 40:303-324. https://doi.org/10.1016/j.geobios.2006.11.001

Fisher, S. 1855. Beitrag zur kenntnis der Ostracoden. Abhandlungen der MatematischPhysikalischen classe der Koeniglich Bayerischen Akademie der Wissenschaften, 7:635666.

Frenzel, P., Schulze, I., Pint, A., Boomer, I., and Feike, M. 2011. Salinity dependant morphological variation in Cyprideis torosa. Joannea Geologie and Paläontologie, 11:59-61.

Gartner, S. and Bukry, D. 1974. Ceratolithus acutus Gartner and Bukry n. sp. and Ceratolithus amplificus Bukry and Percival-nomenclatural clarification. Tulane Studies in Geology and Paleontology. 11(2):115-118.

Gliozzi, E. 1999. A late Messinian brackish water ostracod fauna of Paratethyan aspect from Le Vicenne Basin (Abruzzi, central Apennines, Italy). Palaeogeography, Palaeoclimatology, Palaeoecology, 151:191-208. https://doi.org/10.1016/s0031-0182(99)00023-1 
Gliozzi, E., Ceci, M.E., Grossi, F., and Ligios, S. 2007. Paratethyan ostracod immigrants in Italy during Late Miocene. Geobios, 40:325-337. https://doi.org/10.1016/j.geobios.2006.10.004

Gliozzi, E. and Grossi, F. 2008. Late Messinian Lago-mare ostracod palaeoecology: A correspondence analysis approach. Palaeogeography, Palaeoclimatology, Palaeoecology, 264:288-295. https://doi.org/10.1016/j.palaeo.2007.03.055

Grasso, M., Lentini, F., Nairm A.E.M., and Vigliotti, L. 1983. A geological and paleomagnetic study of the Hyblean volcanic rocks, Sicily. Tectoniphysics, 98:271-295. https://doi.org/ 10.1016/0040-1951(83)90298-6

Gross, M. 2004. Zur Ostracodenfauna (Crustacea), Paläoökologie und Stratigrafie der Tongrube Mataschen (Unter-Pannonium, Steirisches Becken, Österreich). Joannea Geologie and Paläontologie, 5:49-129.

Gross, M., Minati, K., Danielopol, L., and Piller, W.E. 2008. Environmental changes and diversification of Cyprideis in the Late Miocene of the Styrian Basin (Lake Pannon, Austria). Senckenbergiana Lethaea, 88:161-181. https://doi.org/10.1007/bf03043987

Grossi, F. and Gennari, R. 2008.Palaeoenvironmental reconstruction across the Messinian Zanclean boundary by means of ostracods and foraminifers: the Montepetra borehole (Northern Apennine, Italy). Atti del Museo Civico di Storia Naturale di Trieste, 53 (Suppl.):6788.

Grossi, F., Gliozzi, E., Anadónc, P., Castorina, F., and Voltaggio, M. 2015. Is Cyprideis agrigentina Decima a good paleosalinometer for the Messinian Salinity Crisis? Morphometrical and geochemical analyses from the Eraclea Minoa section (Sicily). Palaeogeography, Palaeoclimatology, Palaeoecology, 419:75-89. https://doi.org/10.1016/ j.palaeo.2014.09.024

Grossi, F., Gliozzi, E., and Cosentino, D. 2011. Paratethyan ostracod immigrants mark the biostratigraphy of the Messinian Salinity Crisis. Joannea Geologie and Paläontologie, 11:6668.

Guerra-Merchán, A., Serrano, F., Garcés, M., Gofas, S.. Esu, D., Gliozzi, E., and Grossi, F. 2010. Messinian Lago-Mare deposits near the Strait of Gibraltar (Malaga Basin, S Spain). Palaeogeography, Palaeoclimatology, Palaeoecology, 285:264-276. https://doi.org/10.1016/ j.palaeo.2009.11.019

Hsü, K.J., Ryan, W.F.B., and Cita, M.B. 1973. Late Miocene desiccation of the Mediterranean. Nature, 242:240-244. https://doi.org/10.1038/242240a0

Jones, T.R. 1850. Description of Entomostraca of the Pleistocene beds of Newbury, Copford, Clacton and Grays. Annals and Magazine of Natural History, 2(6):25-28.

Jones, T.R. 1857. A monograph of the Tertiary Entomostraca of England. Palaeontographical Socitey of London, 9(2):1-68.

Kollmann, K. 1960. Cytherideinae und Schulerideinae n. subfam. (Ostracoda) aus dem Neogen des Ostl. Oesterreich. Mitteilungen des Geologischen Gesellschaft in Wien, 51:89-155.

Kováč, M., Barath, I., Kovačova-Slamkova, M., Pipík, R., Hlavaty, I., and Hudačkova, N. 1998. Late Miocene paleoenvironments and sequence stratigraphy: Northern Vienna Basin. Geologica Carpathica, 49:445-458.

Krijgsman, W., Hilgen, F.J., Raffi, I., Sierro, F.J., and Wilson, D.S. 1999. Chronology, causes and progression of the Messinian Salinity Crisis. Nature, 400:652-655. https://doi.org/10.1038/ 23231

Krstć, N. 1968. Ostracodes des Couches Congeriennes: 3, Cyprideis II. Bulletin du Museum d'Histoire Naturelle (Beograd), Série A, 23:153-183.

Latreille, P.A. 1806. Genera crustaceorum et insectorum secundum ordinem naturalem in familias disposita, iconibus exemplisque plurimis explicata. A. Koenig, Parisiis et Argentorati.

Lentini, F., Grasso, M., and Carbone, S. 1987. Introduzione alla geologia della Sicilia e guida all'escursione. Convegno della Società Geologica Italiana, Naxos-Pergusa 22-25 Aprile, 1987. Istituto di Scienze della Terra, Società Geologica Italiana, Catania.

Ligios, S. and Gliozzi, E. 2012. The genus Cyprideis Jones, 1857 (Crustacea, Ostracoda) in the Neogene of Italy: a geometric morphometric approach. Joannea Geologie und Paläontologie, 11:110-112. https://doi.org/10.1016/j.revmic.2012.09.002

Linnaeus, C. 1753. Species plantarum. Laurentii Salvii. Holmiae.

Livental, V.E. 1929. [Ostracoda from the Akchagyl and Apscheron strata along the Babazansk section]. (Publisher unknown), Bacu. (In Russian)

Lucena-Moya, P., Abraín, R., Pardo, I., Hermida, B., and Domínguez, M. 2012. Invertebrate species list of coastal lagoons in the Balearic Islands. Transitional Waters Bulletin, 4:1-11. 
Martini, E. 1971. Standard Tertiary and Quaternary calcareous nannoplankton zonation, p. 739785. In Farinacci, A. (ed.), Proceedings of the 2nd International Planktonic Conference, Rome, Vol. 2. Tecnoscienza, Rome.

Matzke-Karasz, R. and Witt, W. 2005. Ostracods of the Paratethyan Neogene Kılıç and Yalakdere Formations near Yalova (İzmit Province, Turkey). Zitteliana, A45:115-133.

Medley, P., Tibert, N.E., Patterson, W.P., Allen, C.H., Greer, L., and Colin, J.-P. 2007. Paleosalinity history of middle Holocene lagoonal and lacustrine deposits in the Enriquillo Valley, Dominican Republic based on pore morphometrics and isotope geochemistry of ostracoda. Micropaleontology, 53:409-419. https://doi.org/10.2113/gsmicropal.53.5.409

Méhes, G. 1908. Beitrage zur Kenntnis der pliozanen Ostrakoden Ungarns. II. Die Darwinulidaeen und Cytheridaeen der unterpannonischen Stufe. Foldtani Kozlony, Supplement, 38:601-635.

Meisch, C. 2000. Freshwater Ostracoda of Western and Central Europe (Süßwasserfauna von Mitteleuropa 8/3). Spektrum Akademischer, Heidelberg.

Mezquita, F., Aguilar-Alberola, J.A., Carbonell, E., Escrivà, A., Rueda, J., Schmit, O., and Zamora, L. 2011. Introducciò als ostracodes (Crustacea: Ostracoda) castellonencs, p. 37-46. In (editor unknown), Actes del $1^{\circ}$ congrés sobre fauna Castellonenca. Ajuntament de Castelló, Castelló.

Mottura, A. 1871. Sulla formazione terziaria della zona solfifera della Sicilia. Memorie descrittive della Carta Geologica d'Italia, 1:50-140.

Nazik, A., Turkmen, B., Koc, C., Aksoy, E., Avşar, N., and Yayik, H. 2008. Fresh and brackish water ostracods of Upper Miocene deposits, Arguvan/Malatya (Eastern Anatolia). Turkish Journal of Earth Sciences, 17:481-495.

Ogniben, L. 1957. Petrografia della serie solfifera siciliana e considerazioni geologiche relative. Memorie descrittive della Carta Geologica d'Italia, 33:1-276.

Olteanu, R. 1978. Ostracoda from DSDP Leg 42b. Initial Report of Deep Sea Drilling Project, 42(2):1017-1038. https://doi.org/10.2973/dsdp.proc.42-2.145.1978

Olteanu, R. 1982. Genus Tyrrhenocythere Ruggieri, in the Dacic Basin. Dari de Seama ale Sedintelor Institutul de Geologie si Geofizica, 3, Paleontologie, 69:47-58.

Olteanu, R. and Jipa, C. 2006. Dacian Basin environmental evolution during Upper Neogene within the Paratethys domain. Geo-Eco-Marina, 12:91-105.

Olteanu, R. and Vekua, M.L. 1989. Quelques considérations sur les genres Tyrrhenocythere (Ruggieri, 1955) et Hemicytheria (Pokorny, 1955) (Ostracoda, Crustacea) du Néogène supérieur de la Paratéthys. Geobios, 22:78-94. https://doi.org/10.1016/s00166995(89)80089-0

Opreanu, P. 2004. Contribution to the knowledge of recent ostracod fauna from some Danube delta lakes. Geo-Eco-Marina, 9-10:1-3.

Orszag-Sperber, F., Pouchy, J.-M., and Blanc-Valleron, M.-M. 2000. La transition Messinien Pliocène en Méditerranée orientale (Chypre): la période du Lago - Mare et sa signification. Earth and Planetary Sciences and Letters, 331:483-490. https://doi.org/10.1016/S12518050(00)01433-6

Pedley, M. and Grasso, M. 1992. Miocene syntectonic sedimentation along the western margins of the Hyblean-Malta platform: A guide to plate margin processes in the central Mediterranean. Journal of Geodynamics, 15:19-37. https://doi.org/10.1016/02643707(92)90004-C

Pipík, R. 2007. Phylogeny, palaeoecology, and invasion of non-marine waters by the late Miocene Hemicytherid ostracod Tyrrhenocythere from Lake Pannon. Acta Palaeontologica Polonica, 52:351-368.

Puri, H.S. 1953.The Ostracode genus Hemicythere and its allies. Journal of the Washington Academy of Sciences, 43:169-179.

Radu, E. and Stoica, M. 2005. Lower Sarmatian microfauna from the hydrogeological Wellfa Hârlău (laşi county). Acta Palaeontologica Romaniae, 5:413-421.

Romeo, M. and Sciuto, F. 1987. Stratigrafia micropaleontologica delle successioni mioceniche dell'alta valle del fiume Tellaro (Sicilia sud orientale). Memorie della Società Geolologica Italiana, 38:137-154.

Rouchy, J.M. and Caruso, A. 2006. The Messinian salinity crisis in the Mediterranean Basin: a reassessment of the data and an integrated scenario. Sedimentary Geology, 188-189:35-67. https://doi.org/10.1016/j.sedgeo.2006.02.005 
Rouchy, J.M., Caruso, A., Pierre, C., Blanc-Valleron, M.M., and Bassetti, M.A. 2007. The end of the Messinian salinity crisis: evidences from the Chelif Basin (Algeria). Palaeogeography, Palaeoclimatology, Palaeoecology, 254:386-417. https://doi.org/10.1016/ j.palaeo.2007.06.015

Rouchy, J.M., Orszag-Sperber, F., Blanc-Valleron, M.M., Pierre, C., Rivière, M., CombourieuNebout, N., and Panayides, I. 2001. Paleoenvironmental changes at the Messinian-Pliocene boundary in the eastern Mediterranean: southern Cyprus basins. Sedimentary Geology, 145:93-117. https://doi.org/10.1016/s0037-0738(01)00126-9.

Roveri, M., Flecker, R., Krijgsman, W., Lofi, J., Lugli, S., Manzi, V., Sierro, J. F., Bertini, A., Camerlenghi, A., De Lange, G., Govers, R., Hilgen, F.J., Hübscher, C., Meijer, Th.P., and Stoica, M. 2014. The Messinian Salinity Crisis: Past and future of a great challenge for marine sciences. Marine Geology, 352:25-58. https://doi.org/10.1016/j.margeo.2014.02.002.

Roveri, M., Lugli, S., Manzi, V., Gennari, R., laccarino, S.M., Grossi, F., and Taviani, M. 2006. The record of the Messinian events in the Northern Apennines foreland basins. RCMNS Interim Colloquium 2006 "The Messinian Salinity Crisis revisited II", Pre-Congress Field Trip Guide. Acta Naturalia de l'Ateneo Parmense, 42:47-125.

Roveri, M., Manzi, V., Gennari, R., laccarino, S., and Lugli, S. 2008. Recent advances in the Messinian stratigraphy of Italy and their Mediterranean-scale implication. Bollettino della Società Paleontologica Italiana, 47:71-85.

Ruggieri, G. 1955. Tyrrhenocythere a new recent ostracode genus from the Mediterrenean. Journal of Paleontology, 29:698-699.

Ruggieri, G. 1967. The Miocene and later evolution of the Mediterranean Sea, p. 283-290. In Adams, C.G. and Ager, D.V. (eds.), Aspects of Tethyan Biogeography. Systematics Association, Publication 7, The Systematics Association, London.

Şafak, Ü., Avşar, N., and Meriç, E. 1999. Batı Bakırköy (İstanbul) Tersiyer Çökellerinin Ostrakod ve Foraminifer Topluluğu. Maden Tetkik ve Arama Dergisi (Bulletin of the Mineral Research and Exploration), 121:17-31.

Sars, G.O. 1866. Oversight af Norges marine Ostracoder. Forhandlinger $i$ Videnskabs Selskabet i Christiania, 8:1-130.

Sars, G.O. 1887. Nye bidrag til kundskaben om middelhavets invertebratfauna: 4. Ostracoda mediterranea (sydeuropaiske ostracoder). Archiv for Mathematik og Naturvidenskab, 12:173324.

Sars, G.O. 1925. An account of the Crustacea of Norway. Vol. 9. Ostracods. Parts 11, 12, Cytheridae. A. Cammermeyer, Christiania.

Schornikov, E. 2015. The taxonomic position of the Cyprideis species (Ostracoda, Cytherideidae) that occurs in Lake Issyk-Kul, NE Kyrgyzstan. Micropaleontology, 61:37-48.

Sciuto, F. 2011. Distribution of some species of fresh and brackish-water Ostradoda from the Lower Pleistocene of SE Sicily. Biogeographia, 30:62-68. https://doi.org/10.21426/ b630110599

Sciuto, F., Rosso, A., Sanfilippo, R., and Maniscalco, R. 2015. New faunistic data on the Pleistocene environmental evolution of the south-western edge of the Hyblean Plateau (SE Sicily). Carnets de Géologie, 15:41-57. https://doi.org/10.4267/2042/56401

Snel, E., Mărunţeanu, M., Macaleţ, R., Meulenkamp, J.E., and Vugt, N. van. 2006. Late Miocene to Early Pliocene chronostratigraphic framework for the Dacic Basin, Romania. Palaeogeography, Palaeoclimatology, Palaeoecology, 238:107-124. https://doi.org/10.1016/ j.palaeo.2006.03.021

Soulié-Märsche, I. and García, A. 2015. Gyrogonites and oospores, complementary viewpoints to improve the study of the charophytes (Charales). Aquatic Botany, 120:7-17. https://doi.org/ 10.1016/j.aquabot.2014.06.003

Stoica, M., Krijgsman, W., Fortuin, A., and Gliozzi, E. 2016. Paratethyan ostracods in the Spanish Lago-Mare: More evidence for interbasinal exchange at high Mediterranean sea level. Palaeogeography, Palaeoclimatology, Palaeoecology, 441:854-870. https://doi.org/ 10.1016/j.palaeo.2015.10.034

Suzin, A.V. 1956. Ostracodny treticnyh otlozenij Severnogo Predkavkazia: Gost. ord. Trud. k. z. neft. Gostoptehizdat, Moscow.

Trenkwalder, S., Violanti, D., D’Atri, A., Lozar, F., De la Pierre, F., and Irace, A. 2008. The Miocene/Pliocene boundary and the Early Pliocene micropalaeontological record: new data from the Tertiary Piedmont Basin (Moncucco quarry, Torino Hill, Northwestern Italy). Bollettino della Società Paleontologica Italiana, 47:87-103. 
Tunoğlu, C. 2001. Pontian aged Loxoconcha (Ostracoda) species from eastern Black Sea Region of Turkey. Yerbilimleri, 24:127-142.

Valls, L., Rued, J., and Mesquita-Joanes, F. 2013. Dynamics of Ostracoda (Crustacea) assemblages in a Mediterranean pond system (Raco' de l'Olla, Albufera Nat. Park) with focus on the exotic species Candonocypris novaezelandiae (Baird, 1843). Annales de Limnologie-International Journal of Limnology, 49:237-247. https://doi.org/10.1051/limn/ 2013053

van Baak, C.G.C., Stoica, M., Grothe, A., Aliyeva, E., and Krijgsman, W. 2016. MediterraneanParatethys connectivity during the Messinian salinity crisis: The Pontian of Azerbaijan. Global and Planetary Change, 141:63-81. https://doi.org/10.1016/j.gloplacha.2016.04.005

Witt, W. 2011. Mixed ostracod faunas, co-occurrence of marine Oligocene and non-marine Miocene taxa at Pınarhisar, Thrace, Turkey. Zitteliana, A51:237-254.

Wouters, K. 2002. On the distribution of Cyprideis torosa (JONES) (Crustacea, Ostracoda) in Africa, with the discussion of a new record from the Seychelles. Bulletin de L'institut Royal des Sciences Naturelles de Belgique, Biologie, 72:131-140.

Wouters, K. 2016. On the modern distribution of the euryhaline species Cyprideis torosa (Jones, 1850) (Crustacea, Ostracoda). Journal of Micropalaeontology, 36:21-30. https://doi.org/10.1144/ jmpaleo2015-021

Zalanyi, B. 1929. Morpho-systematische Studien uber fossile Muschelkrebse. Geologica Hungarica Series Palaeontologica, 5:1-181. 